\title{
Pemberdayaan Wanita Tani dalam Penerapan Low External Input and Sustainable Agriculture (LEISA) untuk Rumah Pangan Lestari di Kecamatan Cibeureum
}

\author{
Sri Lestaria ${ }^{a}$, Muhammad Tassim Billah ${ }^{a}$, Dedy Kusnadi ${ }^{a}$ \\ ${ }^{a}$ Politeknik Pembangunan Pertanian Bogor, Indonesia \\ Corresponding author: slestari12499@gmail.com
}

\section{Article Info}

Article history:

Received 23 July 2021

Received in revised from 02 August 2021

Accepted 24 September 2021

DOI: https://doi.org/10.32938/ag.v6i3.1422

\section{Keywords:}

Empowerment

LEISA

Women Farmer's

\begin{abstract}
Abstrak
Empowerment of women farmers is one of the keys to success that affects the economic pace of farming families. Through the goal of the sustainable food house movement that synergizes with the application of the LEISA concept, it can maximize local resources and combine various components in an environmentally friendly farming system. Facts on the ground state that $33.5 \%$ of women farmers do not understand the importance of using inputs from within. This research was conducted to describe the empowerment of women farmers and to analyze the factors that influence the empowerment of women farmers as well as to develop strategies to improve the empowerment of women farmers in the application of LEISA for sustainable food houses. The conclusion of the study shows that the empowerment of women farmers who are assessed based on knowledge, attitudes and skills is in the moderate category, while the derivative influence of the dependent variable is influenced by the characteristics of women farmers, biophysical aspects, support for extension services and external factors which mean that women farmers need to be guided and directed properly. synergistic as a goal in achieving increased knowledge, attitudes and skills in supporting the implementation of LEISA for sustainable food houses. Strategies to increase women's empowerment in implementing LEISA for sustainable food houses can be carried out through 1) women's ability to make decisions, 2) use local resources, 3) increase support for extension services, and 4) provide relevant information sources and local government support. in achieving environmentally friendly sustainable agriculture.
\end{abstract}

\section{Pendahuluan}

Perkembangan dunia pertanian dan industri dalam sistem pertanian modern saat ini ternyata menghasilkan dampak negatif yang besar terhadap ekosistem alam. Ketahanan pangan (resistens) hama yang semakin meningkat terhadap pestisida akibat penyemprotan yang semakin tinggi serta pencemaran air tanah maupun sungai oleh senyawa nitrat akibat penggunaan pupuk yang berlebihan. FAO memperkirakan 25\% lahan pertanian mengalami kerusakan terutama $70 \%$ pada lahan jangkauan (range land), lahan kering dan lahan tadah hujan 40\%, dan bahkan 30\% lahan irigasi (FAO, 2011).

Lahan pertanian tepatnya di Kota Tasikmalaya pada tahun 2019 seluas 12.168 Ha. Jumlah produksi tanaman hortikultura sayuran cukup menggembirakan karena terdapat peningkatan dengan pertumbuhan yang bagus yaitu rata-rata 25,82\% per tahun (DKPP Kota Tasikmalaya, 2020). Kecamatan Cibeureum sebagai daerah yang termasuk ke dalam kategori dataran sedang dengan ketinggian daerahnya berada pada kisaran $250 \mathrm{~m}$ dpl sampai dengan $448 \mathrm{~m}$ dpl. Dilihat dari kemiringan lahannya memiliki kemiringan lahan sedang, sehingga perkembangan kegiatan pertanian pada daerah tersebut perlu dilakukan secara selektif (Programa pertanian Kecamatan Cibeureum, 2018).

Keberlanjutan pertanian di masa depan sangatlah tergantung dengan keberlanjutan dalam menjaga unsur-unsur lingkungan di dalamnya. Salah satu alternatif usaha pertanian di masa mendatang adalah LEISA (Low External Input and Sustainable Agriculture), yang merupakan suatu pola dalam pertanian yang berfungsi untuk mengoptimalkan pemanfaatan sumber daya lokal yang ada di lingkungan sekitar, dengan adanya berbagai kombinasi komponen dalam sistem usahatani yang bersinergi, serta pemanfaatan input luar apabila diperlukan hanya sebagai pelengkap peningkatan efektivitas sumber daya dan meminimalkan kerusakan lingkungan. Fakta di lapangan menyebutkan bahwa $33,5 \%$ wanita tani kurang paham mengenai pentingnya penggunaan input dari dalam atau secara alami pada penggunaan pupuk organi serta dalam penggunaan pestisida organik yang ramah lingkungan (RKTP Kecamatan Cibeureum, 2020).

\section{Metode}

Kegiatan penelitian dilaksanakan pada bulan April sampai dengan Juni 2021 yang berlokasi di Kelurahan Setiaratu, Kelurahan Setiajaya, dan Kelurahan Kersanagara Kecamatan Cibeureum Kota Tasikmalaya Provinsi Jawa Barat. Populasi dalam penelitian ini sebanyak 103 orang dengan menggunakan teknik purposive sampling. Penentuan sampel penelitian dilakukan menggunakan 
teori slovin yang dikombinasikan dengan teori Rubbin and Luck untuk mendapatkan proporsional sampel sebanyak 53 orang dengan rumus sebagai berikut:

$n i=\frac{N k}{N} x n$

Dengan:

$\mathrm{ni}=$ Jumlah wanita tani sampel dari masing-masing kelompok

$\mathrm{Nk}=$ Jumlah wanita tani dari masing-masing kelompok yang memenuhi syarat sebagai sampel

$\mathrm{N}=$ Jumlah total petani dari semua kelompok

$\mathrm{n}=$ Jumlah petani yang akan diambil dalam penelitian

Berdasarkan hasil perhitungan didapatkan sampel 5 kelompok wanita tani masing-masing berjumlah 13 orang dari kelompok wanita tani Assalam, 8 orang dari kelompok wanita tani AlBarokah, 15 orang dari kelompok wanita tani Mekarjaya, 8 orang dari kelompok wanita tani Sinar Jaya, dan 9 orang dari kelompok wanita tani Sinar Rembulan. Berdasarkan hasil uji validitas pada instrumen penelitian diperoleh 11 butir soal dinyatakan tidak valid maka dilakukan pemangkasan butir soal menjadi 85 butir soal valid digunakan secara utuh dijadikan sebagai kuesioner dalam kegiatan penelitian. Hasil perhitungan diperoleh nilai reliabilitas menunjukkan nilai Cronbach's' alpha dari kelima variabel bebas melebihi angka 0,70. Kelima variabel tersebut memperoleh nilai sebesar 0,989. Penelitian ini menggunakan desain penelitian kausal dimana desain penelitian ini disusun untuk meneliti kemungkinan adanya hubungan sebab akibat antar variabel. Pendekatan penelitian menggunakan pendekatan kuantitatif didukung dengan data-data kualitatif. Data primer dilakukan secara langsung dengan observasi lapangan serta wawancara terstruktur kepada wanita tani yang menjadi sampel penelitian. Data sekunder diperlukan untuk mendukung capaian penelitian ini.

Dalam melakukan analisis data tentunya disesuaikan dalam menjawab tujuan penelitian. Tujuan pertama yaitu mendeskripsikan pemberdayaan wanita tani dalam penerapan LEISA untuk rumah pangan lestari dilakukan secara deskriptif kualitatif. Guna mengenali deskripsi masingmasing indikator, maka perhitungannya didasarkan pada pengelompokkan menjadi 3 bagian yakni tinggi, sedang serta rendah. Untuk menentukan interval 3 kategori tersebut, maka digunakan rumus sebagai berikut.

$$
\text { interval perkategori }=\frac{(\text { skor maksimal } X \text { jumlah soal })-(\text { skor minimal } X \text { jumlah soal })}{\text { Jumlah Kategori }}
$$

Tujuan kedua yaitu menganalisis faktor-faktor yang mempengaruhi pemberdayaan wanita tani dalam penerapan LEISA untuk rumah pangan lestari dilakukan menggunakan analisis regresi linier berganda untuk menguji pengaruh variabel bebas terhadap variabel terikat. Penelitian ini menggunakan 5 variabel independen dan 1 variabel dependen utama yang difokuskan pada turunannya yaitu 3 variabel dependen. Variabel independen terdiri dari karakteristik wanita tani $\left(\mathrm{X}_{1}\right)$, aspek biofisik $\left(\mathrm{X}_{2}\right)$, aspek sosial ekonomi $\left(\mathrm{X}_{3}\right)$, dukungan layanan penyuluhan $\left(\mathrm{X}_{4}\right)$ dan Faktor eksternal $\left(\mathrm{X}_{5}\right)$. Sedangkan variabel dependen pada penelitian ini $(\mathrm{Y})$ pemberdayaan wanita tani yang diukur berdasarkan perilaku petani yang meliputi pengetahuan $\left(\mathrm{Y}_{1}\right)$, sikap $\left(\mathrm{Y}_{2}\right)$, keterampilan $\left(\mathrm{Y}_{3}\right)$. Adapun persamaan regresi linier berganda yang digunakan sebagai berikut:

$Y_{1}=a+b_{1} X_{1}+b_{2} X_{2}+b_{3} X_{3}+b_{4} X_{4}+b_{5} X_{5}$

$Y_{2}=a+b_{1} X_{1}+b_{2} X_{2}+b_{3} X_{3}+b_{4} X_{4}+b_{5} X_{5}$

$Y_{3}=a+b_{1} X_{1}+b_{2} X_{2}+b_{3} X_{3}+b_{4} X_{4}+b_{5} X_{5}$

Keterangan:

$\mathrm{Y}_{1} \quad=$ Pengetahuan

$\mathrm{Y}_{2} \quad=$ Sikap

$\mathrm{Y}_{3}=$ Keterampilan

a = Bilangan Konstan

$\mathrm{b}_{1-5}=$ Koefisien variabel bebas ke 1-5

$\mathrm{X}_{1-5}=$ Variabel bebas ke 1 sampai 5

Tujuan ketiga dalam penelitian ini yaitu menyusun strategi dalam meningkatkan pemberdayaan wanita tani dalam penerapan LEISA untuk rumah pangan lestari dilakukan penentuan analisis dengan dua pembanding dari hasil perhitungan analisis deskriptif kualitatif dan analisis regresi linier berganda yang nantinya dihasilkan peningkatan keberdayaan wanita tani dalam penerapan LEISA. 


\section{Hasil dan Pembahasan}

\section{Deskripsi Pemberdayaan Wanita Tani}

Deskripsi keragaan karakteristik wanita tani

Penggolongan umur dibagi menjadi 4 kategori berdasarkan data yang diperoleh dalam penyebaran kuesioner terhadap 53 orang wanita tani. Sedangkan tingkat pendidikan formal dikategorikan menjadi 4 kategori yaitu sangat tinggi ditingkat perguruan tinggi, tinggi ditingkat pendidikan SMA, sedang ditingkat pendidikan SMP dan rendah ditingkat pendidikan SD baik tamat atau tidak tamat (Qintamy et al., 2020). Adapun lama berusaha tani dibagi menjadi 4 kategori yaitu sangat berpengalaman dengan lama berusaha tani $>15$ tahun, berpengalaman 11-15 tahun, cukup berpengalaman 6-10 tahun dan kurang berpengalaman <5 tahun (Widyastuti et al., 2014). Kemudian pendidikan non formal dibagi menjadi 4 kategori yaitu sangat rendah, rendah, sedang, dan tinggi (Efu et al., 2020).

Tabel 1. Deskripsi keragaan karakteristik wanita tani

\begin{tabular}{lcc}
\multicolumn{1}{c}{ Kategori } & $\begin{array}{c}\text { Jumlah Responden } \\
\text { (Orang) }\end{array}$ & $\begin{array}{c}\text { Persentase } \\
(\%)\end{array}$ \\
\hline Umur & 3 & 5,6 \\
$66-76$ & 9 & 16,9 \\
$55-65$ & 30 & 56,6 \\
$44-54$ & 11 & 20,7 \\
$33-43$ & & \\
Tingkat Pendidikan Formal & 13 & 24,5 \\
SD (1-6) & 21 & 39,7 \\
SMP (7-9) & 19 & 35,8 \\
SMA (10-12) & 0 & - \\
Sekolah Tinggi (13-16) & & 35,85 \\
Lama Berusaha Tani & 19 & 49,05 \\
Kurang Berpengalaman (<5) & 26 & 15,09 \\
Cukup Berpengalaman (6-10) & 8 & - \\
Berpengalaman (11 - 15) & 0 & 77,3 \\
Sangat Berpengalaman (>15) & & 15 \\
Pendidikan Non Formal & 41 & 1,8 \\
Sangat Rendah (0 - 4) & 8 & 5,6 \\
Rendah (5 - 9) & 1 &
\end{tabular}

Sumber : Analisis data primer diolah penulis, 2021

Hasil penelitian menunjukan bahwa sebagian besar wanita tani berada pada rentang umur (44-54 tahun) atau 56,6 persen sebanyak 30 orang merupakan kisaran umur paling banyak dimiliki oleh wanita tani di daerah tersebut. Pada rentang umur (33-43 tahun) atau 20,7 persen sebanyak 11 orang, kemudian pada umur (55-65 tahun) atau 16,9 persen sebanyak 9 orang dan disisanya berada pada rentang umur (66-76 tahun) atau 5,6 persen sebanyak 3 orang wanita tani.

Tingkat pendidikan formal wanita tani mayoritas berada pada kategori SMP dengan lama bersekolah 7-9 tahun berjumlah 21 orang dengan persentase 39,7 persen. Selanjutnya kategori SMA dengan lama bersekolah 10-12 tahun berjumlah 19 orang dengan persentase 35,8 persen. Dan sisanya berada pada kategori SD dengan lama bersekolah 1-6 tahun yang berjumlah 1 orang dengan persentase 24,5 persen.

Lama berusaha tani menempati kategori cukup berpengalaman 6-10 tahun berjumlah 26 orang dengan persentase 49,05 persen. Selanjutnya pada kategori kurang berpengalaman $<5$ tahun berjumlah 19 orang dengan persentase 35,85 persen dan sisanya berada pada kategori berpengalaman 11-15 tahun berjumlah 8 orang dengan persentase 15,09 persen.

Pendidikan non formal kategori yang menempati kedudukan pertama yakni berada pada kategori sangat rendah 0-4 kali sebanyak 41 orang responden dengan persentase sebesar 77,3 persen. Sementara itu kategori rendah 5-9 kali berada pada persentase 15 persen sebanyak 8 orang. Disusul pula dengan kategori sedang 15-17 kali sebanyak 3 orang dengan persentase 5,6 persen serta sisanya pada kategori tinggi terakhir yakni 10-14 kali sebanyak 1 orang dengan persentase sebesar 1,8 persen.

\section{Deskripsi keragaan aspek biofisik}

Variabel independen aspek biofisik $\left(\mathrm{X}_{2}\right)$ diukur menggunakan 10 soal yang kemudian diinterpretasikan ke dalam 3 kategori. Selanjutnya diuraikan pada tabel 2 dibawah ini. 
Tabel 2. Persentase keragaan aspek biofisik

\begin{tabular}{ccccc}
\hline \multirow{2}{*}{ No } & Indikator & \multicolumn{3}{c}{ Tingkat $100 \%$} \\
\cline { 2 - 4 } & Kualitas Lahan & Rendah & Sedang & Tinggi \\
\hline 1. & Penggunaan input eksternal \& Internal & 7,5 & 45,2 & 47,1 \\
2. & Daur Limbah & 28,3 & 30,1 & 67,9 \\
3. & & & 52,8 & 18,8 \\
\hline
\end{tabular}

Sumber : Analisis data primer diolah penulis, 2021

Hasil analisis menunjukan bahwa terdapat tiga indikator dalam variabel independen $\mathrm{X}_{2}$. Indikator pertama dalam penelitian ini yaitu kualitas lahan. Pada kualitas lahan sebanyak 47,1 persen termasuk dalam kategori tinggi. Kemudian 45,2 persen berada pada kategori sedang dan sisanya pada kategori sedang sebesar 7,5 persen. Indikator kedua yaitu penggunaan input eksternal dan internal. Pada penggunaan input eksternal dan internal sebanyak 67,9 persen berada pada kategori tinggi. Kemudian 30,1 persen berada pada kategori sedang dan sisanya berada pada kategori rendah. Indikator ketiga yaitu daur limbah. Pada indikator ini didapatkan kategori sedang dengan persentase 52,8 persen. Kemudian 28,3 persen berada pada kategori rendah dan sisanya berada pada kategori tinggi dengan persentase 18,8 persen.

Deskripsi keragaan aspek sosial ekonomi

Variabel independen aspek sosial ekonomi $\left(\mathrm{X}_{3}\right)$ diukur menggunakan 10 soal yang kemudian diinterpretasikan ke dalam 3 kategori. Selanjutnya diuraikan pada tabel 3 dibawah ini.

Tabel 3. Persentase aspek sosial ekonomi

\begin{tabular}{ccccc}
\hline \multirow{2}{*}{ No } & Indikator & \multicolumn{3}{c}{ Tingkat $100 \%$} \\
\cline { 3 - 5 } 1. & Diversifikasi sumber pendapatan on-farm, & Sedang & Tinggi \\
\hline 2. & off-farm \& non-farm & 9,4 & 69,8 & 20,7 \\
3. & Ketahanan pangan & 9,4 & 56,6 & 33,9 \\
\hline
\end{tabular}

Sumber : Analisis data primer diolah penulis, 2021

Hasil analisis menunjukan bahwa terdapat tiga indikator dalam variabel independen $\mathrm{X}_{3}$. Indikator pertama dalam penelitian ini yaitu diversifikasi sumber pendapatan on-farm, off-farm dan non-farm. Pada indikator ini didapatkan 69,8 persen berada pada kategori sedang. Kemudian 20,7 persen berada pada kategori tinggi dan sisanya 9,4 persen berada pada kategori rendah. Indikator kedua dalam penelitian ini yaitu ketahanan pangan. Pada indikator ketahanan pangan didapatkan 56,6 persen berada pada kategori sedang. Kemudian 33,9 persen berada pada kategori tinggi dan sisanya berada pada kategori rendah sebesar 9,4 persen. Indikator ketiga dalam penelitian ini yaitu modal sosial. Indikator modal sosial didapatkan 47,1 persen dengan kategori tinggi. Kemudian 43,3 persen berada pada kategori sedang dan sisanya berada pada kategori rendah dengan persentase 9,4 persen.

\section{Deskripsi keragaan dukungan layanan penyuluhan}

Variabel independen dukungan layanan penyuluhan $\left(\mathrm{X}_{4}\right)$ diukur menggunakan 18 soal yang kemudian diinterpretasikan ke dalam 3 kategori. Selanjutnya diuraikan pada tabel 4 dibawah ini.

Tabel 4. Persentase dukungan layanan penyuluhan

\begin{tabular}{ccccc}
\hline \multirow{2}{*}{ No } & Indikator & \multicolumn{3}{c}{ Tingkat $100 \%$} \\
\cline { 2 - 4 } & Rendah & Sedang & Tinggi \\
\hline 1. & Peran Penyuluh & 7,5 & 79,2 & 13,2 \\
2. & Materi & 30,1 & 58,4 & 11,3 \\
3. & Media & 5,6 & 54,7 & 39,6 \\
4. & Metode & 33,9 & 64,1 & 1,8 \\
5. & Sarana Pendukung & 5,6 & 56,6 & 37,7 \\
\hline
\end{tabular}

Sumber : Analisis data primer diolah penulis, 2021

Hasil analisis menunjukan bahwa terdapat lima indikator dalam variabel independen $\mathrm{X}_{4}$. Indikator pertama dalam penelitian ini yaitu peran penyuluh. Pada indikator ini didapatkan 79,2 persen berada pada kategori sedang. Kemudian 13,2 persen berada pada kategori tinggi dan sisanya 7,5 persen berada pada kategori rendah. Indikator kedua dalam penelitian ini yaitu materi. Pada indikator materi didapatkan 58,4 persen berada pada kategori sedang. Kemudia 30,1 persen berada pada kategori rendah dan sisanya berada pada kategori tinggi sebesar 11,3 persen. Selanjutnya indikator ketiga dalam penelitian ini yaitu media. Pada indikator ini didapatkan 54,7 
persen berada pada kategori sedang. Kemudian 39,6 persen berada pada kategori tinggi dan sisanya berada pada kategori rendah dengan persentase 5,6 persen. Indikator selanjutnya yaitu metode. Indikator ini berada pada kategori sedang dengan persentase 64,1 persen. Kemudian sebesar 33,9 persen berada pada kategori rendah dan sisanya berada pada kategori tinggi dengan persentase 1,8 persen. Indikator terakhir dalam variabel $\mathrm{X}_{4}$ yaitu sarana pendukung. Indikator ini berada pada kategori sedang dengan persentase 56,6 persen. Kemudian sebesar 37,7 persen berada pada kategori tinggi dan sisanya berada pada kategori rendah dengan persentase 5,6 persen.

\section{Deskripsi keragaan faktor eksternal}

Variabel independen faktor eksternal $\left(\mathrm{X}_{5}\right)$ diukur menggunakan 11 soal yang kemudian diinterpretasikan ke dalam 3 kategori. Selanjutnya diuraikan pada tabel 5 dibawah ini.

Tabel 5. Persentase faktor eksternal

\begin{tabular}{|c|c|c|c|c|}
\hline \multirow{2}{*}{ No } & \multirow{2}{*}{ Indikator } & \multicolumn{3}{|c|}{ Tingkat $100 \%$} \\
\hline & & Rendah & Sedang & Tinggi \\
\hline 1. & Ketersediaan Sumber Informasi & 5,6 & 60,3 & 33,9 \\
\hline 2. & Peran Kelompok Wanita Tani & 16,9 & 28,3 & 54,7 \\
\hline 3. & Dukungan Pemerintah & 60,3 & 32 & 7,5 \\
\hline
\end{tabular}

Sumber : Analisis data primer diolah penulis, 2021

Hasil analisis menunjukan bahwa terdapat tiga indikator dalam variabel independen $\mathrm{X}_{5}$. Indikator pertama dalam penelitian ini yaitu ketersediaan sumber informasi. Indikator ini berada pada kategori sedang dengan persentase sebesar 60,3 persen. Kemudian 33,9 persen berada pada kategori tinggi dan sisanya berada pada kategori rendah dengan persentase 5,6 persen. Indikator kedua dalam penelitian ini yaitu peran kelompok wanita tani. Indikator ini berada pada kategori tinggi dengan persentase 54,7 persen. Kemudian 28,3 persen berada pada kategori sedang dan sisanya berada pada kategori rendah dengan persentase 16,9 persen. Selanjutnya indikator terakhir pada penelitian ini yaitu dukungan pemerintah. Indikator ini berada pada kategori rendah dengan persentase 60,3 persen. Kemudian sebesar 32 persen berada pada kategori sedang dan sisanya berada pada kategori tinggi dengan persentase 7,5 persen.

\section{Deskripsi keragaan pemberdayaan wanita tani}

Variabel dependen pemberdayaan wanita tani (Y) diukur menggunakan 32 soal yang kemudian diinterpretasikan ke dalam 3 kategori. Selanjutnya diuraikan pada tabel 6 dibawah ini.

Tabel 6. Persentase pemberdayaan wanita tani

\begin{tabular}{|c|c|c|c|c|}
\hline \multirow{2}{*}{ No } & \multirow{2}{*}{ Indikator } & \multicolumn{3}{|c|}{ Tingkat $100 \%$} \\
\hline & & Rendah & Sedang & Tinggi \\
\hline 1. & Pengetahuan & 18,8 & 58,4 & 22,6 \\
\hline 2. & Sikap & 20,7 & 47,1 & 32 \\
\hline 3. & Keterampilan & 30,1 & 64,1 & 5,6 \\
\hline
\end{tabular}

Sumber: Analisis data primer diolah penulis, 2021

Hasil analisis menunjukkan bahwa terdapat tiga indikator dalam variabel dependen Y. Indikator pertama dalam penelitian ini yaitu pengetahuan. Pada indikator pengetahuan berada pada kategori sedang dengan persentase sebesar 58,4 persen. Kemudian 22,6 persen berada pada kategori tinggi dan sisanya berada pada kategori rendah dengan persentase 18,8 persen. Indikator kedua dalam penelitian ini yaitu sikap. Indikator sikap berada pada kategori sedang dengan persentase 47,1 persen. Kemudian 32 persen berada pada kategori tinggi dan sisanya berada pada kategori rendah sebesar 20,7 persen. Selanjutnya indikator terakhir pada penelitian ini yaitu keterampilan. Indikator ini berada pada kategori sedang dengan persentase 64,1 persen. Kemudian 30,1 persen berada pada kategori rendah dan sisanya berada pada kategori tinggi dengan persentase sebesar 5,6 persen.

\section{Faktor yang mempengaruhi pemberdayaan wanita tani}

Pada tabel 7 dapat dilihat bahwa hasil analisis tersebut diperoleh variabel independen faktor eksternal $\left(\mathrm{X}_{5}\right)$ yang memiliki pengaruh signifikan terhadap variabel dependen pemberdayaan wanita tani pada pengetahuan $\left(\mathrm{Y}_{1}\right)$. Adapun persamaannya adalah $\mathrm{Y}_{1}=1,964+0,965 \mathrm{X}_{5}$ dengan taraf nyata 5\%. Persamaan tersebut berarti bahwa faktor eksternal memberikan pengaruh sebesar 0,965. Nilai koefisien determinasi Adjusted R-Squared sebesar 0,220 yang berarti bahwa variabel yang diteliti mempengaruhi pemberdayaan wanita tani pada pengetahuan sebesar 22 persen dan sisanya 78 persen dipengaruhi oleh faktor lain diluar penelitian ini. Selanjutnya semua variabel akan dijelaskan sebagai berikut: 
1. Pengaruh karakteristik wanita tani pada pengetahuan $\left(\mathrm{X}_{1}\right)$

Karakteristik wanita tani tidak memiliki pengaruh terhadap pengetahuan dalam pemberdayaan wanita tani sebesar $0,226>0,05(\mathrm{a}=5 \%)$. Hasil analisa secara statistik menyimpulkan bahwa karakteristik wanita tani dalam penelitian ini harus dapat menunjang mengenai kemampuan wanita tani dalam menumbuhkembangkan kreativitas serta pengambilan keputusan bagi usahataninya. Menurut penelitian yang diungkapkan (Elizabeth, 2007) dan (Astiti et al., 2014) bahwa wanita tani perlu dibina atau dibimbing serta diberdayakan untuk mempercepat proses alih teknologi.

2. Pengaruh aspek biofisik pada pengetahuan $\left(\mathrm{X}_{2}\right)$

Aspek biofisik tidak memiliki pengaruh terhadap pengetahuan dalam pemberdayaan wanita tani sebesar 0,314>0,05 ( $\mathrm{a}=5 \%$ ). Hasil analisa secara statistik menyimpulkan bahwa dalam menjaga lingkungan rumah pangan lestari wanita tani harus konsisten dalam menjamin kualitas lahan, penggunaan input eksternal dan internal serta daur limbah pertanian serta dalam mengambil keputusan yang mengupayakan adanya perubahan bagi permasalahan yang muncul dalam rumah pangan lestari baik dalam budidaya maupun mencapai hasil yang diinginkan. Selaras dengan penelitian (Rusastra et al., 2011) mengemukakan bahwa secara umum permasalahan yang dihadapi dalam pemanfaatan dan pengembangan lahan pekarangan salah satunya kurang tersediannya teknologi budidaya spesifik pada lahan pekarangan dan bersifat sambilan untuk memenuhi kebutuhan rumah tangga dan belum berorientasi pasar.

3. Pengaruh aspek sosial ekonomi pada pengetahuan $\left(\mathrm{X}_{3}\right)$

Aspek sosial ekonomi tidak memiliki pengaruh terhadap pengetahuan dalam pemberdayaan wanita tani sebesar 0,650 $>0,05(\mathrm{a}=5 \%)$. Hasil analisa secara statistik menyimpulkan bahwa aspek sosial ekonomi perlu ditingkatkan dan diperhatikan. Untuk itu hal yang perlu dilakukan dalam peningkatan kapasitas sumber daya petani salah satunya dengan komponen ketahanan pangan yang merupakan hal penting untuk diperhatikan menyangkut rumah tangga wanita tani itu sendiri. Terkait kondisi tersebut, strategi ketahanan pangan akan lebih tepat paling tidak pada tingkat rumah tangga wanita tani dalam pemenuhan kebutuhan. Menurut (Ramakrishna et al., 2012) mengungkapkan bahwa pembentukan dan pengembangan kelompok atau organisasi perempuan tani adalah kunci untuk meningkatkan ketahanan pangan rumah tangga. Sama halnya dengan kondisi wanita tani yang banyak dari anggota kelompok wanita tani masih enggan untuk berempati dan kurang terbuka dalam menyikapi permasalahan usahatani mereka masing-masing. Harapan yang tumbuh didalam perilaku wanita tani adanya perilaku jujur, teratur dan saling bekerjasama antar anggota wanita tani.

4. Pengaruh dukungan layanan penyuluhan pada pengetahuan $\left(\mathrm{X}_{4}\right)$

Dukungan layanan penyuluhan tidak memiliki pengaruh terhadap pengetahuan dalam pemberdayaan wanita tani sebesar 0,732 >0,05 $(\mathrm{a}=5 \%)$. Hasil analisa secara statistik menyimpulkan bahwa dukungan layanan penyuluhan perlu dicermati dan ditelaah kembali. Menurut penelitian (Siregar et al., 2010) bahwa peran penyuluh sangat penting dalam mensosialisasikan teknologi pertanian guna meningkatkan produktivitas pertanian keluarga dan tergantung pada kinerja penyuluh pertanian di lapangan. Di daerah penelitian penyuluh pertanian menggunakan metode anjangsana dan diskusi kelompok sebagai bagian tindak lanjut dan situasi pandemi covid-19 saat ini yang tidak dimungkinkannya mengadakan pertemuan dalam skala besar. Dalam kendala tersebut wanita tani menginginkan intensitas penyuluhan dapat terus diperbaharui kembali guna mencapai target pada masing-masing kelompok wanita tani.

5. Pengaruh faktor eksternal pada pengetahuan $\left(\mathrm{X}_{5}\right)$

Faktor eksternal memiliki pengaruh terhadap pengetahuan dalam pemberdayaan wanita tani sebesar 0,002 >0,05 $(\mathrm{a}=5 \%)$. Hasil analisa secara statistik menyimpulkan bahwa faktor eksternal yang berpengaruh terhadap pengetahuan memberikan gambaran bahwa dalam ketersediaan sumber informasi, peran kelompok wanita tani dan dukungan pemerintah sangatlah perlu dijadikan suatu target atau capaian kedepannya. Hal ini dikarenakan faktor eksternal memberikan dampak yang baik khususnya terhadap individu wanita tani dalam pengembangan pekarangan untuk mencapai target rumah pangan lestari yang ramah lingkungan.

Tabel 7. Faktor yang mempengaruhi pengetahuan

\begin{tabular}{lccc}
\multicolumn{1}{c}{ Uraian } & Nilai & Sig. & Keterangan \\
\hline Adj. R Square & 0,220 & & \\
Konstanta & 1,964 & 0,897 & \\
X $_{1}$ Karakteristik Wanita tani & $-0,071$ & 0,226 & Tidak Berpengaruh \\
X $_{2}$ Aspek Biofisik & 0,226 & 0,314 & Tidak Berpengaruh \\
\hline
\end{tabular}




\begin{tabular}{lllc}
\hline $\mathrm{X}_{3}$. Aspek Sosial Ekonomi & 0,096 & 0,650 & Tidak Berpengaruh \\
$\mathrm{X}_{4}$. Dukungan Layanan Penyuluhan & 0,066 & 0,732 & Tidak Berpengaruh \\
$\mathrm{X}_{5}$. Faktor Eksternal & 0,965 & 0,002 & Berpengaruh \\
\hline Dependent Variable: $Y_{1}$ Pengetahuan
\end{tabular}

Dependent Variable: Y1 Pengetahuan

Sumber: Data primer yang diolah di SPSS versi 26, 2021

\section{Faktor yang mempengaruhi pemberdayaan wanita tani pada sikap}

Pada tabel 8 dapat dilihat bahwa hasil analisis tersebut diperoleh variabel independen aspek biofisik $\left(\mathrm{X}_{2}\right)$, dan faktor eksternal $\left(\mathrm{X}_{5}\right)$ memiliki pengaruh signifikan terhadap variabel dependen pemberdayaan wanita tani pada sikap $\left(\mathrm{Y}_{2}\right)$. Adapun persamaannya adalah $\mathrm{Y}_{2}$ sikap $=12,531+0,380$ $\mathrm{X}_{2}+0,650 \mathrm{X}_{5}$ dengan taraf nyata $5 \%$. Persamaan tersebut berarti bahwa aspek biofisik memberikan pengaruh sebesar 0,380 dan faktor eksternal sebesar 0,650. Nilai koefisien determinasi Adjusted $R$-Squared sebesar 0,242 yang berarti bahwa variabel yang diteliti mempengaruhi pemberdayaan wanita tani pada aspek sikap sebesar 24,2 persen dan sisanya 75,8 persen dipengaruhi oleh faktor lain diluar penelitian ini. Selanjutnya semua variabel akan dijelaskan sebagai berikut:

1. Pengaruh karakteristik wanita tani pada sikap $\left(\mathrm{X}_{1}\right)$

Karakteristik wanita tani tidak memiliki pengaruh terhadap sikap dalam pemberdayaan wanita tani sebesar $0,150>0,05(a=5 \%)$. Hasil analisa secara statistik menyimpulkan bahwa karakteristik wanita tani perlu diperhatikan kembali dalam menyikapi adanya inovasi teknologi ramah lingkungan dengan menekan konsep LEISA bagi rumah pangan lestari. Menurut (Walgito, 2006) menyatakan bahwa sikap yang dimiliki seseorang memberikan corak pada perilaku atau tindakan orang yang bersangkutan. Karakteristik wanita tani dalam penelitian ini menjadi penunjang mengenai kemampuan wanita tani dalam pengambilan sebuah keputusan perihal kegiatan usaha tani secara individu.

2. Pengaruh aspek biofisik pada sikap $\left(\mathrm{X}_{2}\right)$

Aspek biofisik memiliki pengaruh terhadap sikap dalam pemberdayaan wanita tani sebesar $0,036<0,05(a=5 \%)$. Hasil analisa secara statistik menyimpulkan bahwa sspek biofisik yang berpengaruh terhadap sikap memberikan gambaran bahwa kualitas lahan, penggunaan input eksternal dan internal serta daur limbah sangat dapat diterima dan mampu menjadi solusi yang baik dalam pemecahan masalah terkait dengan aspek biofisik pada lingkungan pekarangan. Menurut pendapat dari (Rambe et al., 2011) bahwasanya sikap tidak akan memberi respon secara langsung terhadap suatu perubahan menyadari bahwa pengetahuan dan sikap dipengaruhi oleh pengalaman. Dalam hal tersebut pengalamanlah yang mampu menyadarkan individu atau wanita tani dalam mengambil sebuah keputusan. Keputusan tersebut mengupayakan adanya perubahan bagi permasalahan yang muncul dalam usahataninya baik dalam budidaya maupun sampai hasil yang diinginkan.

3. Pengaruh aspek sosial ekonomi pada sikap $\left(\mathrm{X}_{3}\right)$

Aspek sosial ekonomi tidak memiliki pengaruh terhadap sikap dalam pemberdayaan wanita tani sebesar 0,327 >0,05 $(\mathrm{a}=5 \%)$. Hasil analisa secara statistik menyimpulkan bahwa diversifikasi sumber pendapatan mengarah on-farm, off-farm dan non-farm, ketahanan pangan serta modal sosial perlu dicermati dan diperhatikan kembali. Menurut pendapat dari (Farhan et al.,2010) menyatakan bahwa rendahnya kualitas konsumsi pangan berdampak terhadap rendahnya kualitas sumber daya manusia.

4. Pengaruh dukungan layanan penyuluhan pada sikap $\left(\mathrm{X}_{4}\right)$

Dukungan layanan penyuluhan tidak memiliki pengaruh terhadap sikap dalam pemberdayaan wanita tani sebesar $0,498>0,05(\mathrm{a}=5 \%)$. Hasil analisa secara statistik menyimpulkan bahwa peran penyuluh, materi, media, metode serta sarana pendukung perlu ditinjau dan diperhatikan kembali. Menurut pandangan (Rogers et al.,1971) menyatakan bahwa individu pada sistem sosial yang berorientasi pada perubahan yang selalu memperbarui diri, terbuka pada hal-hal baru dan giat mencari informasi. Salah satu cara untuk menumbuhkan sikap atau orientasi pada perubahan ini adalah dengan memilih inovasi-inovasi yang layak untuk diperkenalkan secara berurutan.

5. Pengaruh faktor eksternal pada sikap $\left(\mathrm{X}_{5}\right)$

Faktor eksternal memiliki pengaruh terhadap sikap dalam pemberdayaan wanita tani sebesar $0,009<0,05(a=5 \%)$. Hasil analisa secara statistik menyimpulkan bahwa faktor eksternal yang berpengaruh terhadap sikap memberikan gambaran bahwa dalam ketersediaan sumber informasi, peran kelompok wanita tani dan dukungan pemerintah mampu berperan dengan baik. Hal ini dikarenakan faktor eksternal memberikan dampak yang baik khususnya terhadap individu wanita tani dalam menggembangkan usahataninya baik dalam pemanfaatan pekarangan untuk rumah pangan lestari. 
Tabel 8. Faktor yang mempengaruhi sikap

\begin{tabular}{lccc}
\multicolumn{1}{c}{ Uraian } & Nilai & Sig. & Keterangan \\
\hline Adj. R Square & 0,242 & & \\
Konstanta & 12,531 & 0,303 & \\
X $_{1}$ Karakteristik Wanita tani & $-0,067$ & 0,150 & Tidak Berpengaruh \\
X. $_{2}$ Aspek Biofisik & 0,380 & 0,036 & Berpengaruh \\
X $_{3}$ Aspek Sosial Ekonomi & 0,166 & 0,327 & Tidak Berpengaruh \\
X $_{4}$ Dukungan Layanan Penyuluhan & $-0,103$ & 0,498 & Tidak Berpengaruh \\
X. Faktor Eksternal & 0,650 & 0,009 & Berpengaruh \\
\hline
\end{tabular}

Dependent Variable: $\mathrm{Y}_{2}$ Sikap

Sumber: Data primer yang diolah di SPSS versi 26, 2021

\section{Faktor yang mempengaruhi pemberdayaan wanita tani pada keterampilan}

Pada tabel 9 dapat dilihat bahwa hasil analisis diperoleh bahwa variabel independen karakteristik wanita tani $\left(\mathrm{X}_{1}\right)$, aspek biofisik $\left(\mathrm{X}_{2}\right)$, dukungan layanan penyuluhan $\left(\mathrm{X}_{4}\right)$, dan faktor eksternal $\left(\mathrm{X}_{5}\right)$ memiliki pengaruh signifikan terhadap variabel dependen pemberdayaan wanita tani pada keterampilan $\left(\mathrm{Y}_{3}\right)$. Adapun persamaannya adalah $\mathrm{Y}_{3}$ Keterampilan $=7,752+0,062 \mathrm{X}_{1}+0,156$ $\mathrm{X}_{2}+0,118 \mathrm{X}_{4}+0,195 \mathrm{X}_{5}$ dengaan taraf nyata $5 \%$. Persamaan tersebut berarti bahwa karakteristik wanita tani memberikan pengaruh sebesar 0,062, aspek biofisik sebesar 0,156, dukungan layanan penyuluhan sebesar 0,118 dan faktor eksternal sebesar 0,195. Nilai koefisien determinasi Adjusted $R$-Squared sebesar 0,320 yang berarti bahwa variabel yang diteliti mempengaruhi pemberdayaan wanita tani pada aspek keterampilan sebesar 32 persen dan sisanya 68 persen dipengaruhi oleh faktor lain diluar penelitian ini. Selanjutnya semua variabel akan dijelaskan sebagai berikut:

1. Pengaruh karakteristik wanita tani pada keterampilan $\left(\mathrm{X}_{1}\right)$

Karakteristik wanita tani memiliki pengaruh terhadap keterampilan dalam pemberdayaan wanita tani sebesar 0,001 $<0,05(a=5 \%)$. Hasil analisa secara statistik menyimpulkan bahwa karakteristik wanita tani yang berpengaruh terhadap keterampilan memberikan gambaran bahwa umur bukanlah menjadi penghambat dalam melakukan kegiatan usahatani. Tingkat pendidikan formal berkaitan erat dengan keberadaan dan ketersediaan sumberdaya manusia berkualitas dan berdaya saing. Selain hal tersebut lama berusaha tani dan pendidikan non formal dengan lamanya kegiatan berusahatani maka keterampilan dan kecenderungan pada diri wanita tani dalam menghasilkan produk usahataninya akan lebih baik dibandingkan dengan yang baru masuk menjadi anggota kelompok wanita tani. Menurut pendapat (Kristina et al., 2019) dikatakan bahwa pendidikan wanita tani yang rendah tidak membuat pengalaman mereka untuk bertani rendah pula. Dengan tujuan agar dapat meningkatkan keterampilan wanita tani dalam berusahatani, meningkatkan pemanfaatan lahan pekarangan, meningkatkan gizi keluarga serta dapat memotivasi wanita tani untuk maju dan produktif sehingga dapat meningkatkan pendapatan rumah tangga wanita tani bagi rumah pangan lestari.

2. Pengaruh aspek biofisik pada keterampilan $\left(\mathrm{X}_{2}\right)$

Aspek biofisik memiliki pengaruh terhadap keterampilan dalam pemberdayaan wanita tani sebesar 0,023 $<0,05(a=5 \%)$. Hasil analisa secara statistik menyimpulkan bahwa aspek biofisik yang berpengaruh terhadap keterampilan memberikan gambaran bahwa kualitas lahan, penggunaan input eksternal dan internal serta daur limbah sangat perlu ditingkatkan. Dalam menjaga lingkungan rumah pangan lestari wanita tani harus konsisten dalam menjamin dan menjaga keadaan tanah, tekstur tanah pada tanaman pekarangannya. Menurut (Reijntjes, 2006) dengan pengelolaan sumberdaya yang berhasil untuk usaha pertanian guna membantu kebutuhan manusia yang berubah sekaligus mempertahankan atau meningkatkan kualitas lingkungan dan melestarikan sumber daya alam.

3. Pengaruh aspek sosial ekonomi pada keterampilan $\left(\mathrm{X}_{3}\right)$

Aspek sosial ekonomi tidak memiliki pengaruh terhadap keterampilan dalam pemberdayaan wanita tani sebesar 0,462 >0,05 $(a=5 \%)$. Hasil analisa secara statistik menyimpulkan bahwa memberikan gambaran bahwa diversifikasi sumber pendapatan mengarah on-farm, off-farm dan non-farm, ketahanan pangan serta modal sosial merupakan usaha untuk memperoleh target dan peningkatan kemampuan. Selaras dengan pendapat (Farhan et al., 2010) menyatakan bahwa rendahnya kualitas konsumsi pangan berdampak terhadap rendahnya kualitas sumber daya manusia. Meskipun koefisien pengaruhnya relatif kecil namun aspek sosial ekonomi masih dapat meningkatkan keterampilan terhadap penerapan LEISA untuk rumah pangan lestari.

4. Pengaruh dukungan layanan penyuluhan pada keterampilan $\left(\mathrm{X}_{4}\right)$

Dukungan layanan penyuluhan memiliki pengaruh terhadap keterampilan dalam pemberdayaan wanita tani sebesar 0,045 $<0,05(a=5 \%)$. Hasil analisa secara statistik menyimpulkan bahwa dukungan layanan penyuluhan yang berpengaruh terhadap 
keterampilan memberikan gambaran bahwa indikator peran penyuluh, materi, media, metode serta sarana pendukung sangat perlu untuk diasah dan lebih menguasai penerapan LEISA bagi rumah pangan lestari. Sependapat dengan penelitian (Siregar et al., 2010) bahwa peran penyuluh sangat penting dalam mensosialisasikan teknologi pertanian guna meningkatkan produktivitas pertanian keluarga dan tergantung pada kinerja penyuluh pertanian di lapangan.

5. Pengaruh faktor eksternal ada keterampilan $\left(\mathrm{X}_{5}\right)$

Faktor eksternal memiliki pengaruh terhadap keterampilan dalam pemberdayaan wanita tani sebesar 0,034 $<0,05(\mathrm{a}=5 \%)$. Hasil analisa secara statistik menyimpulkan bahwa faktor eksternal yang berpengaruh terhadap keterampilan dimaknai bahwa dalam ketersediaan sumber informasi, peran kelompok wanita tani dan dukungan pemerintah sangatlah penting untuk ditingkatkan serta menambah keterampilan dalam diri wanita tani tersebut. Menurut pendapat yang dikemukakan oleh (Bemmelen, 1995) dalam (Endang et al., 2014) bahwa di sektor publik perlu adanya peningkatan status wanita tani dalam kehidupan bermasyarakat dengan cara memberikan dukungan agar wanita tani lebih banyak berperan sebagai subyek, meningkatkan pengetahuan, keterampilan dan kesempatan lebih banyak untuk berperan sebagai perencana dan pengambil keputusan dalam bidang pertanian. Model LEISA sebagai model yang tepat dan sesuai dengan kondisi keberagaman ekosistem dan kekayaan sumberdaya alam yang dimiliki. Dengan demikian sangat diperlukan perhatian dan dukungan pemerintah daerah setempat melalui semua instansi terkait untuk mengembangkannya sebagai program prioritas pembangunan pertanian.

Tabel 9. Faktor yang mempengaruhi keterampilan

\begin{tabular}{lccc}
\multicolumn{1}{c}{ Uraian } & Nilai & Sig. & Keterangan \\
\hline Adj. R Square & 0,320 & & \\
Konstanta & 7,752 & 0,093 & \\
X $_{1}$ Karakteristik Wanita tani & 0,062 & 0,001 & Berpengaruh \\
X $_{2}$ Aspek Biofisik & 0,156 & 0,023 & Berpengaruh \\
X $_{3}$ Aspek Sosial Ekonomi & 0,047 & 0,462 & Tidak Berpengaruh \\
X. Dukungan Layanan Penyuluhan & 0,118 & 0,045 & Berpengaruh \\
X. Faktor Eksternal & 0,195 & 0,034 & Berpengaruh \\
\hline
\end{tabular}

Dependent Variable: $\mathrm{Y}_{3}$ Keterampilan

Sumber: Data primer yang diolah di SPSS versi 26, 2021

\section{Strategi Peningkatan Pemberdayaan wanita tani}

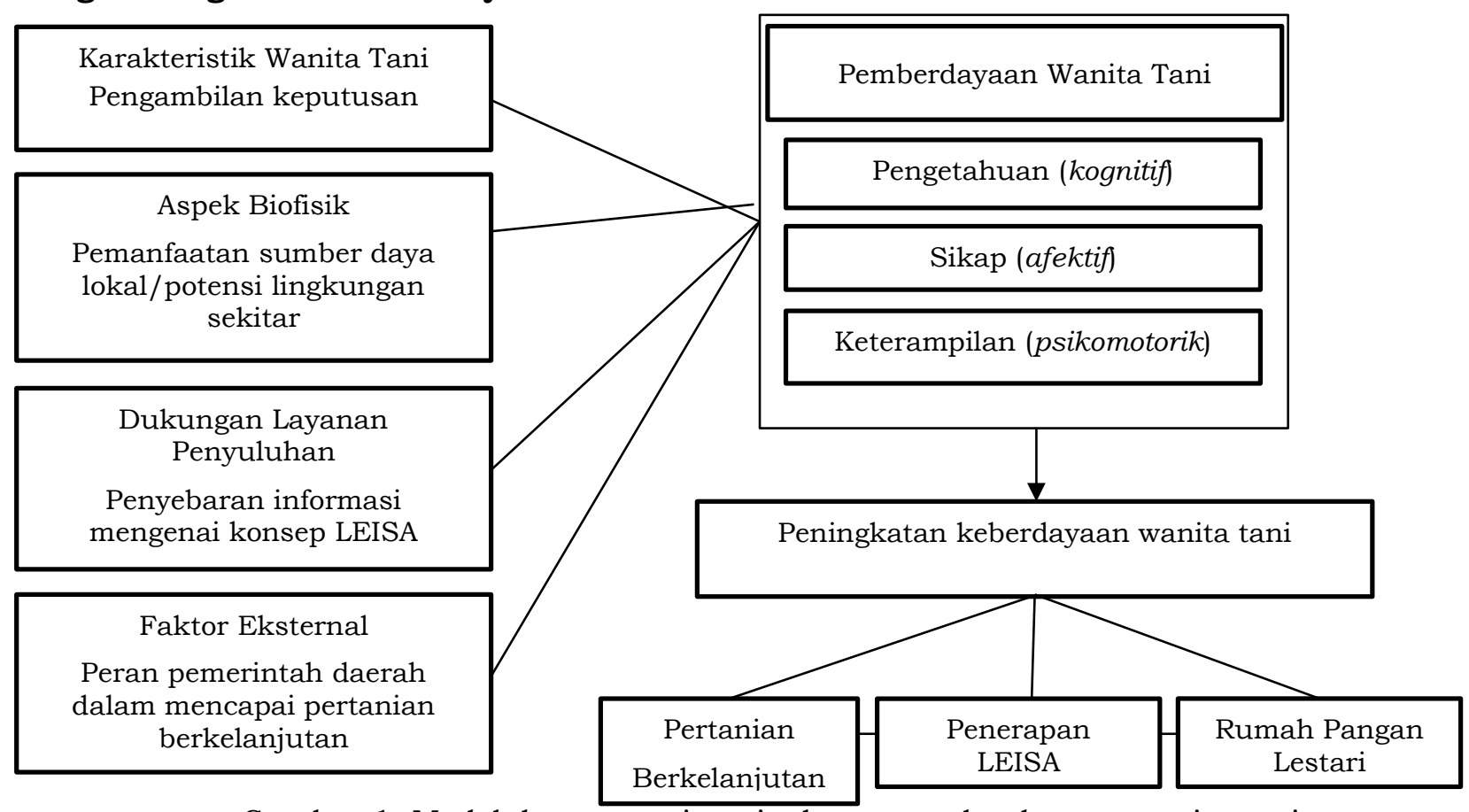

Gambar 1. Model dan strategi peningkatan pemberdayaan wanita tani

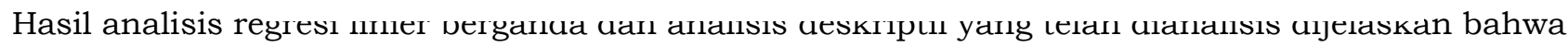
adanya pengaruh dari masing-masing variabel independen terhadap variabel dependen. Maka pada gambar diatas model strategi dalam peningkatan keberdayaan wanita tani yang diukur dalam 
pengetahuan, sikap serta keterampilan dalam penerapan LEISA untuk rumah pangan lestari sebagai berikut:

1. Kemampuan wanita tani dalam mengambil sebuah keputusan mengenai rumah pangan lestari dalam penerapan LEISA.

2. Pemanfaatan sumber daya lokal pada daur limbah mampu ditangani bersama-sama dimulai dari pemanfaatan limbah pertanian maupun non pertanian untuk mendukung pertanian yang berkelanjutan.

3. Meningkatan dukungan layanan penyuluhan mampu mempercepat penyebaran informasi mengenai penerapan LEISA untuk rumah pangan lestari.

Menyediakan sumber informasi yang relevan dari sektor pertanian serta dukungan pemerintah daerah dalam mencapai pertanian berkelanjutan yang ramah lingkungan.

\section{Simpulan}

Pemberdayaan wanita tani yang dinilai berdasarkan aspek pengetahuan, sikap dan keterampilan wanita tani tergolong dalam kategori sedang. Umur wanita tani mayoritas termasuk pada kategori umur produktif. Tingkat pendidikan formal termasuk dalam kategori Sekolah Menengah Pertama (SMP). Wanita tani mayoritas merupakan wanita tani dengan kategori cukup berpengalaman. Dan pendidikan non formal yang sudah dilakukan mayoritas berada dalam kategori sangat rendah. Aspek biofisik rata-rata didominasi oleh kategori tinggi. Kemudian pada aspek sosial ekonomi, dukungan layanan penyuluhan serta faktor eksternal rata-rata didominasi oleh kategori sedang. Pemberdayaan wanita tani dalam penerapan LEISA untuk rumah pangan lestari dipengaruhi secara signifikan oleh karakteristik wanita tani, aspek biofisik, dukungan layanan penyuluhan dan faktor eksternal. Strategi peningkatan pemberdayaan wanita tani dalam penerapan LEISA untuk rumah pangan lestari dapat dilakukan melalui 1) Kemampuan wanita tani dalam mengambil keputusan; 2) Pemanfaatan sumber daya lokal; 3) Peningkatan dukungan layanan penyuluhan; dan 4) Penyediaan sumber informasi yang relevan serta dukungan pemerintah daerah dalam mencapai pertanian berkelanjutan yang ramah lingkungan.

\section{Pustaka}

Astiti, N. S., \& Tenaya, I. N. (2014). Peran Wanita Tani dalam Penerapan Teknologi Pengelolaan Tanaman Terpadu (PTT) pada Usahatani Jagung di Kecamatan Pringgabaya Kabupaten Lombok Timur. Jurnal Manajemen Agribisnis, 2(2), 26286.

Bemmelen, S. V. (1995). Jender dan Pembangunan: Kajian Wanita dalam Pembangunan. Penyunting T. O Ihromi. Jakarta Yayasan Obor Indonesia.

BPP Kecamatan Cibeureum. 2018. Programa Balai penyuluh pertanian (BPP) Kecamatan Cibeureum.

DKPP Kota Tasikmalaya. 2020. Data Dinas Ketahanan Pangan, Pertanian, Perikanan, Kota Tasikmalaya.

Efu, A., \& Simamora, T. (2021). Karakteristik Peternak dan Dukungan Penyuluhan dalam Mendukung Kemampuan Manajerial Beternak Sapi Potong di Desa Oepuah Utara. AGRIMOR, 6(1). https:/ / doi.org/10.32938/ag.v6i1.1229

Elizabeth, R. (2007). Pemberdayaan wanita mendukung strategi gender mainstreaming dalam kebijakan pembangunan pertanian di perdesaan.

Farhan, M., \& Firmansyah, A. (2010). Keanekaragaman dan Kecukupan Konsumsi Pangan Hewani dalam Hubungannya dengan Kualitas Sumberdaya Manusia Keluarga di Provinsi Jambi. Jurnal Penelitian Universitas Jambi: Seri Humaniora, 12(1), 43413.

Kristina, A., \& Immamudin, I. (2019). Konflik Gender di Pasar Tenaga Kerja Wanita Tani (Studi Fenomenologi Wanita Tani dalam Membuat Keputusan Kerja). Simulacra, 2(1), 91-100.

Nations, O. (2011). State of the World's Land and Water Resources for Food and Agriculture.

Qintamy, R. A., Harniati, H., \& Kusnadi, D. (2020). Tingkat Keberdayaan Petani dalam Penerapan Low External Input Sustainable Agriculture (LEISA) pada Budidaya Ubi Jalar di Kecamatan Cilawu Kabupaten Garut. JIA (Jurnal Ilmiah Agribisnis): Jurnal Agribisnis Dan Imu Sosial Ekonomi Pertanian, 5(4). https://doi.org/10.37149/jia.v5i4.13046.

Ramakrishna, R., Subbarao, N., \& Chiranjeevi, C. (2012). Role of women in improving household food security in India. Indian Journal of Agricultural Economics, 67(3), 525.

Rambe, S. S. M., \& Bunaiyah, H. (2011). Perilaku petani dalam usahatani padi di lahan rawa lebak. Reijntjes, dkk. 2006. Pertanian Masa Depan (Pengantar untuk pertanian).

Endang P, R., Tenaya, N., \& Astiti, S. (2014). Peran Wanita Tani dalam Penerapan Teknologi Pengelolaan Tanaman Terpadu (PTT) pada Usahatani Jagung di Kecamatan Pringgabaya Kabupaten Lombok Timur. Jurnal Manajemen Agribisnis, 2(1).

RKTP BPP Kecamatan Cibeurem. 2019. Rencana Kerja Tahunan Penyuluh Pertanian Balai Penyuluh Pertanian Kecamatan Cibeurem Berdasarkan Kelurahan Setiaratu, Setiajaya dan Kersanagara. 
Rogers, E. M., \& Shoemaker, F. F. (1971). Communication of Innovations; A Cross-Cultural Approach.

Rusastra, I. W., Susilowati, S. H., \& Situmorang, J. (2011). Dampak Pengembangan Model Kawasan Rumah Pangan Lestari terhadap Kesejahteraan Rumah Tangga dan Ekonomi di Perdesaan. Pusat Sosial Ekonomi dan Kebijakan Pertanian.

Siregar, A. N., \& Saridewi, T. R. (2010). Hubungan antara Motivasi dan Budaya Kerja dengan Kinerja Penyuluh Pertanian di Kabupaten Subang, Provinsi Jawa Barat. Jurnal Penyuluhan Pertanian, 5(1).

Walgito, Bimo. 2006. Psikologi Sosial suatu Pengantar (Edisi Revisi). Penerbit Andi. Yogyakarta. Widyastuti, N., Slamet, M., dan Ginting, B. 2014. Partisipasi Petani dalam Programa Pengabdian Masyarakat melalui Pola Sekolah Lapangan. Jurnal Penyuluhan Pertanian. 09(2). 